\title{
Physical activity and quality of life of children and adolescents with cystic fibrosis: a cross-sectional study
}

\author{
Atividade física e qualidade de vida de crianças e \\ adolescentes com fibrose cística: um estudo transversal
}

\author{
Taiane dos Santos Feiten (D) [a], Josani da Silva Flores ${ }^{(D)}[a]$, Paula Maria Eidt Rovedder ${ }^{(D)}{ }^{[a]}$, Paulo de Tarso \\ Roth Dalcin (D) [a,b], Bruna Ziegler (D) [a]*
}

[a] Universidade Federal do Rio Grande do Sul (UFRGS), Porto Alegre, RS, Brazil

${ }^{[b]}$ Hospital de Clínicas de Porto Alegre (HCPA), Porto Alegre, RS, Brazil

\begin{abstract}
Introduction: Regular physical activity (PA) is part of outpatient care offered to most people with cystic fibrosis (CF). Objective: To determine the frequency of the self-reported PA and, secondarily evaluate associations between PA with clinical variables and health-related quality of life (HRQoL) in pediatric and adolescent CF subjects. Method: In this cross-sectional study, subjects between 6 and 17 years of age with a confirmed diagnosis of $\mathrm{CF}$ were recruited in the outpatient clinic. The subjects answered questions about the practices of PA, HRQoL questionnaire and clinical variables were collected. Subjects were classified into two groups according to weekly PA practice: PA performed $\geq 3$ times/week and performed PA $\leq 2$ times/week. Results: 66 subjects completed the study, $72.7 \%(n=48)$ had PA $\geq 3$ times/week and $27.2 \%$ $(\mathrm{n}=18)$ had $\mathrm{PA} \leq 2$ times/week. Only twelve children $(18,2 \%)$ reached the recommendations of the World Health Organization (WHO) to practice moderate to vigorous physical activities daily. The mean age of the subjects evaluated was $12.3 \pm 3.2$ years, forced expiratory volume in one second $90 \pm 24.1 \%$ and
\end{abstract}

*TSF: MS, e-mail: taifeiten@gmail.com

JSF: Doctoral student, e-mail: josiflores@hotmail.com

PMER: PhD, e-mail: larove_@hotmail.com

PTRD: PhD, e-mail: pdalcin@terra.com.br

BZ: PhD, e-mail: brunaziegler@yahoo.com.br 
forced vital capacity $95 \pm 20.4 \%$. The group that performed PA $\geq 3$ times/week had a better clinical score $(\mathrm{p}=0.033)$, a lower number of hospitalizations in the year $(\mathrm{p}=0.002)$, a lower number of days hospitalized in the last year $(p=0.020)$ and better score for the physical $(p=0.003)$ and emotion $(p=0.048)$ domains in HRQoL questionnaire. Conclusion: This study concluded that most subjects did not reach the WHO recommendations for the practice of PA. However, individuals who practice PA at least 3 times/week have better HRQoL, clinical score and fewer hospitalizations.

Keywords: Pediatrics. Health Related Quality of Life. Exercise. Respiratory Function Tests. Clinical Score.

\section{Resumo}

Introdução: A atividade física regular (AF) faz parte do tratamento ambulatorial oferecido à maioria das pessoas com fibrose cística (FC). Objetivo: Determinar a frequência da AF autorreferida e secundariamente avaliar as associações entre AF e variáveis clínicas e de qualidade de vida relacionada à saúde (QVRS) em crianças e adolescentes com FC. Método: Neste estudo transversal, indivíduos entre 6 e 17 anos com diagnóstico confirmado de FC foram recrutados no ambulatório. Os sujeitos responderam perguntas sobre as práticas de AF, questionário de QVRS e variáveis clínicas. Os indivíduos foram classificados em dois grupos de acordo com a prática semanal de $A F$ : $A F$ realizada $\geq 3$ vezes/semana e $A F \leq 2$ vezes/semana. Resultados: 66 indivíduos completaram o estudo, $72,7 \%$ ( $n=48$ ) tinham $A F \geq 3$ vezes/semana e 27,2\% ( $n=18$ ) tinham $A F \leq 2$ vezes/semana. Apenas doze crianças (18,2\%) alcançaram as recomendações da Organização Mundial da Saúde (OMS) para praticar diariamente atividades físicas moderadas a vigorosas. A média de idade dos sujeitos avaliados foi de $12,3 \pm 3,2$ anos, volume expiratório forçado no primeiro segundo $90 \pm 24,1 \%$ e capacidade vital forçada $95 \pm$ $20,4 \%$. O grupo que realizou $A F \geq 3$ vezes/semana apresentou melhor escore clínico ( $p=0,033)$, menor número de internações no ano $(p=0,002)$, menor número de dias hospitalizados no último ano $(p=0,020)$ e melhor escore para os domínios físico $(p=0,003)$ e emoção $(p=0,048)$ no questionário de QVRS. Conclusão: Este estudo concluiu que a maioria dos indivíduos não alcançou as recomendações da OMS para a prática de AF. No entanto, indivíduos que praticam AF pelo menos 3 vezes/semana apresentam melhor QVRS, escore clínico e menos hospitalizações.

Palavras-chave: Pediatria. Qualidade de Vida Relacionada com Saúde. Exercício. Testes de Função Respiratória. Pontuação Clínica.

\section{Introduction}

Cystic fibrosis (CF) is an autosomal recessive, multisystemic disease characterized by cystic fibrosis conduction regulator (CFTR) dysfunction, with consequent airway obstruction, progressive loss of lung function, and exercise limitation. It affects individuals of all ethnicities with higher prevalence in Caucasians [1].

Soon after birth, structural changes of the airways are already present, with infection and pulmonary inflammation [2]. The progression of respiratory obstruction and destruction of lung tissue result in the development of bronchiectasis, narrowing of the airway walls and pulmonary hyperinflation [3]. These changes interfere with the pulmonary ventilation / perfusion ratio, triggering hypoxemia, dynamic hyperinflation during exercise and dyspnea on effort [4]. Exercise intolerance evolves to diminishing physical effort, limiting activities of daily living, decreasing healthrelated quality of life (HRQoL), and life expectancy [5].

Regular physical activity (PA) is part of outpatient care offered to most people with $\mathrm{CF}$, and has a positive impact on aerobic fitness with no reports of side effects [6]. The PA can provide socialization, self-knowledge, physical and psychological development, as well it is regarded as an effective and funny strategy for the development of children. The encouragement to practice PA should be started at early age and at any stage of the disease [7].

Self-report measures of physical activity have been used for nearly 50 years, to determine the frequency, duration, intensity, and type of physical activity in various populations and health conditions [8]. Currently, there are no specific instruments that assess self-reported PA 
in CF population. In addition, there is a great variety of the methodologies used $[7,8]$. In CF clinical practice, the multidisciplinary team routinely monitored selfreported physical activity levels and exercise capacity of outpatient subjects. PA had a positive impact on the HRQoL of CF subjects in different studies, which varies depending of questionnaires used. The Revised Cystic Fibrosis Questionnaire (CFQ-R) [9] was the most used tool to evaluate HRQoL in subjects with CF [6].

The main objective of this study was to determine the self-reported frequency of PA in pediatric and adolescent CF subjects. The secondary objective was to evaluate associations between frequency of PA with HRQoL, lung function, clinical score, bacterial colonization and hospitalizations in the last year.

\section{Method}

This cross-sectional study included CF subjects attending the outpatient clinic of the Pediatric Pulmonology Service of the Hospital de Clínicas de Porto Alegre (HCPA). The study sample was non-probabilistic and intentional and all subjects who met the inclusion criteria and agreed to participate in the study were included sequentially. Inclusion criteria were: diagnosis of CF according to consensus criteria[10], age between 6 to 17 years and clinical stability of the disease defined as at least 30 days without pulmonary exacerbation or hospitalization.

Exclusion criteria were: difficulties in answering the questionnaires. The study was approved by the Research Ethics Committee of the HCPA protocol number 140157 and the informed consent was obtained from parents or guardians.

Patients (sometimes with the assistance of their caregivers) self-reported PA in the last two weeks by answering a questionnaire (number of times per week, duration and type of PA performed). The days and hours of physical activities performed at school or in extracurricular activities such as swimming, judo, ballet, football and cycling were computed. According to the World Health Organization (WHO), children and young people aged 5 to 17 years must accumulate at least 60 minutes of moderate to vigorous physical activity daily[11]. However, for individuals with CF, the recommendation is to perform PA 3 to 5 times a week for 20 to 30 minutes [12]. In this work, we classified as active those who performed PA at least 3 times a week. The Compendium of Physical Activities [13] was used to classify the intensity of the PA reported in the questionnaire. This instrument provides a list of physical activities and classify the intensity of PA in moderate ( $\geq 3$ METS) and (vigorous $\geq 6$ METS).

The HRQoL questionnaire developed for subjects with CF [14] and validated for Portuguese [15], was used in the study.

Data on the following variables were recorded at the entry date in the study: sex, age, age of diagnosis of CF, body mass index (BMI), sputum bacteriology, lung function data, days of hospitalizations, number of hospitalizations in the last year and clinical score of Shwachman-Kulczycki (SK). The SK score is divided into four domains: general activity; physical examination; nutrition; and radiological finding. The scores of the four domains are summed to obtain the final score, from which the condition of the patient is categorized as excellent (86-100), good (71-85), average (56-70), poor $(41-55)$ or severe $(\leq 40)[16]$.

Spirometry was performed at the Pulmonary Physiology Unit of the Pulmonology Service of the HCPA, using the equipment Jaeger - v 4.31a (Jaeger, Wuerzburg, Germany), within the criteria of technical acceptability of the Guidelines for Pulmonary Function Tests of the Brazilian Society of Pulmonology and Tisiology [17]. A minimum of three and a maximum of eight maneuvers were performed to obtain forced vital capacity (FVC), forced expiratory volume in the first second (FEV1) and FEV1/FVC in absolute values and percentage of predicted $[18,19]$.

\section{Statistical Analysis}

Data were entered into a Microsoft Excel 365 database after which they were processed and analyzed with the Statistical Package for the Social Sciences (SPSS), version 20.0.

Quantitative data were presented as mean and standard deviation (SD) or as median (interquartile deviation - ID). Qualitative data will be expressed in $n$ ( $\%$ of all cases).

Patients were classified into two groups according to the frequency of PA performed: $\mathrm{PA} \geq 3$ times/week or PA $\leq 2$ times/week Continuous variables were compared by the independent sample t-test. Ordinal variables or continuous variables without normal distribution were compared by the Wilcoxon signed-rank test. Qualitative data were analyzed with the chi-square test, Yates' correction or Fisher's exact test being used when 
necessary. All statistical tests were two-tailed, and the level of significance was set at $\mathrm{p}<0.05$.

\section{Results}

Among 109 subjects attending the CF outpatient clinic of the Pediatric Pulmonology of HCPA, 72 fulfilled the inclusion criteria of this study. Two subjects were excluded, one due to pulmonary exacerbation requiring hospitalization and the other due to parents' refusal to participate. Four other subjects did not attend consultations. A total of 66 individuals completed the study.

Only 12 children $(18,2 \%)$ reached the recommendations of the WHO to practice moderate to vigorous physical activities daily. Table 1 describe general characteristics and frequency of PA of children and adolescents with CF. Forty-eight subjects (72,7\%) perform $\mathrm{PA} \geq 3$ times/week and 18 subjects $(27,2 \%)$ perform $P A \leq 2$ times/week or did not perform PA. The mean age of the subjects evaluated was $12.3 \pm 3.2$ years, FEV1 $90.0 \pm 24.1 \%$ of predicted and FVC $95.0 \pm 20.4 \%$ of predicted.

Table 2 describes the general characteristics and pulmonary function variables of subjects according to the frequency of PA. The group that performed $\mathrm{PA} \geq 3$ times/week had a higher proportion of male individuals, a better clinical score ( $p=0.033)$, a lower number of hospitalizations in the last year $(\mathrm{p}=0.002)$ and a lower number of days of hospitalization in the last year $(\mathrm{p}=0,020)$.

Table 3 presents the HRQoL variables according to the performance of PA. The group that practiced PA $\geq 3$ times/week presented better scores for the physical ( $p$ $=0.003)$ and emotion $(\mathrm{p}=0.048)$ domains.

Table 1 - General characteristics and frequency of physical activity of children and adolescents with CF

\begin{tabular}{lc}
\hline Variable & Mean \pm SD \\
\hline Age (years) & $12.3 \pm 3.2$ \\
FEV $_{1}(\%)$ & $90.0 \pm 24.1$ \\
FVC (\%) & $95.0 \pm 20.4$ \\
\hline Frequency of PA & $\mathbf{n ~ ( \% )}$ \\
\hline Did not perform & $27.72 \%$ \\
One time a week & $18.81 \%$ \\
Two times a week & $12.87 \%$ \\
Three times a week & $11.88 \%$ \\
Four times a week & $0.99 \%$
\end{tabular}

\begin{tabular}{ll} 
Five times a week & $7(10.6)$ \\
Six times a week & $8(12.1)$ \\
Seven times a week & $12(18.2)$ \\
\hline
\end{tabular}

Note: $\mathrm{PA}=$ physical activity, $\mathrm{CF}=$ cystic fibrosis, $\mathrm{n}=$ number of cases, $\mathrm{SD}=$ standard deviation, FEV1 = forced expiratory volume in the first second, FVC = forced vital capacity.

Table 2 - General characteristics of children and adolescents with cystic fibrosis according to the frequency of physical activity

\begin{tabular}{|c|c|c|c|}
\hline Variable & $\begin{array}{c}P A \geq 3 x / \\
\text { week } \\
n=48\end{array}$ & $\begin{array}{c}P A \leq 2 x / \\
\text { week } \\
n=18\end{array}$ & $\mathbf{p}$ \\
\hline $\begin{array}{l}\text { Age (years), mean } \\
\pm \text { SD }\end{array}$ & $12.38 \pm 3.1$ & $11.94 \pm 3.3$ & 0.998 \\
\hline $\begin{array}{l}\text { Age of diagnosis } \\
\text { (years), median (II) }\end{array}$ & $1.40(2.2)$ & $1.58(2.5)$ & 0.782 \\
\hline $\begin{array}{l}\text { Gender (n) Female } \\
\text { / Male }\end{array}$ & $21 / 27$ & $14 / 4$ & 0.014 \\
\hline $\begin{array}{l}\mathrm{BMI}\left(\mathrm{Kg} / \mathrm{m}^{2}\right) \text {, mean } \\
\pm \mathrm{SD}\end{array}$ & $18.4 \pm 2.1$ & $18 \pm 3.3$ & 0.685 \\
\hline $\begin{array}{l}\text { S-K total (points), } \\
\text { mean } \pm \text { SD } \\
\text { Bacterial } \\
\text { colonization, n (\%) }\end{array}$ & $79.1 \pm 12.6$ & $71.1 \pm 15.1$ & 0.033 \\
\hline MSSA & 37 (72.2) & $13(77.1)$ & 0.682 \\
\hline MRSA & $3(6.2)$ & $4(22.2)$ & 0.061 \\
\hline $\begin{array}{l}\text { Pseudomonas } \\
\text { aeruginosa }\end{array}$ & $27(56.2)$ & $9(50)$ & 0.650 \\
\hline $\begin{array}{l}\text { Burkholderia } \\
\text { cepacia } \\
\text { Spirometry, (mean } \\
\pm \text { SD) }\end{array}$ & $9(18.8)$ & $4(22.2)$ & 0.752 \\
\hline FVC (L) & $2.6 \pm 0.9$ & $2.3 \pm 0.9$ & 0.097 \\
\hline FVC (\%) & $97 \pm 18.8$ & $89.2 \pm 23.9$ & 0.178 \\
\hline $\mathrm{FEV}_{1}(\mathrm{~L})$ & $2.3 \pm 0.8$ & $1.9 \pm 0.8$ & 0.099 \\
\hline $\mathrm{FEV}_{1}(\%)$ & $92.1 \pm 21.8$ & $84.2 \pm 28.8$ & 0.297 \\
\hline $\mathrm{FEV}_{1} / \mathrm{FVC}$ & $82.2 \pm 9.7$ & $80.4 \pm 11.8$ & 0.531 \\
\hline $\mathrm{FEV}_{1} / \mathrm{FVC}(\%)$ & $97.4 \pm 11.3$ & $95 \pm 14.1$ & 0.477 \\
\hline $\begin{array}{l}\text { Number of } \\
\text { hospitalizations/year, } \\
\text { median (II) }\end{array}$ & $0.6(1)$ & $1.6(1.2)$ & 0.002 \\
\hline $\begin{array}{l}\text { Number of days } \\
\text { hospitalized /year, } \\
\text { median (II) }\end{array}$ & $12(27.8)$ & 30.7 (29.6) & 0.020 \\
\hline
\end{tabular}

Note: $\mathrm{SD}=$ standard deviation, $\mathrm{BMI}=$ body mass index, MRSA = Methicillin-resistant Staphylococcus aureus, MSSA = Methicillin susceptible Staphylococcus aureus, SK = score of ShwachmanKulczycki, FVC = forced vital capacity, $\mathrm{FEV}_{1}=$ forced expiratory volume in the first second, $\mathrm{FEV}_{1} / \mathrm{FVC}=$ Tiffeneau index. 
Table 3 - Health-related quality of life according to the frequency of physical activity of children and adolescents with cystic fibrosis

\begin{tabular}{lccc}
\hline Variable & $\begin{array}{c}\text { PA } \geq \mathbf{3 x /} \\
\text { week } \\
\mathbf{n = 4 8}\end{array}$ & $\begin{array}{c}\text { PA } \leq \mathbf{2 x /} \\
\text { week } \\
\mathbf{n = 1 8}\end{array}$ & $\mathbf{p}$ \\
\hline $\begin{array}{l}\text { HRQoL score } \\
\text { (points), mean } \\
\pm \text { SD }\end{array}$ & & & \\
Physical & $85.3 \pm 14.9$ & $65.8 \pm 20.8$ & 0.003 \\
Emotion & $82.2 \pm 12.6$ & $69.4 \pm 16.6$ & 0.048 \\
Nutrition & $84.7 \pm 19.2$ & $77.7 \pm 29.5$ & 0.391 \\
$\begin{array}{l}\text { Difficulty in } \\
\text { treatment }\end{array}$ & $75.7 \pm 20.6$ & $62.5 \pm 27.4$ & 0.097 \\
Social & $73.6 \pm 20.1$ & $75.1 \pm 15.3$ & 0.790 \\
Body or body & $83 \pm 25.2$ & $85.4 \pm 13.2$ & 0.724 \\
image & $73.5 \pm 17.4$ & $65.2 \pm 24.3$ & 0.165 \\
Breath & $79.2 \pm 24.2$ & $93 \pm 15.1$ & 0.015 \\
Digestion & $78.3 \pm 16.6$ & $60.4 \pm 7.9$ & 0.055 \\
\hline Vitality & $79.2 \pm 19.6$ & $75 \pm 16.6$ & 0.698 \\
\hline Health & & & \\
perceptions & $81.1 \pm 20.2$ & $87.5 \pm 10.7$ & 0.557 \\
Function & $73.3 \pm 31.3$ & $75 \pm 49.9$ & 0.934 \\
Weight & & & \\
\hline
\end{tabular}

Note: $\mathrm{SD}=$ standard deviation, $\mathrm{HRQOL}=$ health-related quality of life.

\section{Discussion}

This cross-sectional study evaluated the self-reported frequency of PA in pediatric and adolescent subjects attending to a pediatric outpatient CF clinic in Southern Brazil. Among 66 subjects included in the study, only twelve patients $(18,2 \%)$ reached the recommendations of the WHO to practice moderate to vigorous physical activities daily. Subjects were divided into two groups according to their weekly PA practices: $72,7 \%$ had PA $\geq 3$ times/week and $27.2 \%$ had PA $\leq 2$ times/week. Participants who had PA $\geq 3$ times/week presented better HRQoL in the physical and emotional domains. The group that performed PA $\leq 2$ times/week had a worse clinical score, a higher number of hospitalizations and a greater number of days hospitalized in the last year.

The routinely evaluation of the self-reported PA could play a role in CF clinical practice, allowing professionals to monitor and encourage exercise, promoting health. Currently, there are no specific instruments that evaluate self-reported PA in this population, and different methodologies are available to evaluate the same outcome [20]. In the present work, we used a questionnaire developed by the authors that consisted of simple questions of frequency, duration and type of activities performed in the last two weeks. This questionnaire has not been validated and may generate a bias in the collection and interpretation of data. However, Ruf et al. [21] compared the Habitual Activity Estimation Scale, the 7-day physical activity questionnaire and the Lipid Research Clinics questionnaire with objective measures accessed by accelerometry and cycloergometry. In conclusion, the authors suggest that none of the assessed questionnaires was able to generate valid data on physical activity, exercise performance data at the individual level and none of the questionnaires provided a valid assessment of aerobic fitness at the individual level [21]. The PA in CF subjects has been recognized since the clinical aspects of the disease were identified, and exercise intolerance has always been a hallmark of disease progression [6]. In this study, $81.8 \%$ of the subjects did not reach the WHO recommendations for PA practice. This number can be even higher when we consider the subjectivity of instrument.

In the present work, self-reported PA had a positive impact on HRQoL (physical and emotional functioning domains) in subjects who practiced $P A \geq 3$ times/week. The physical domain of the HRQoL questionnaire covers items such as how much the child was able to perform physical activities such as climbing stairs, walking fast or playing sports in relation to other children in the last two weeks. This domain was significantly different between the groups, supporting our findings in PA questionnaire. Previous studies have shown similar results, showing that PA improves HRQoL in terms of physical functioning, treatment load, emotional functioning, body image, social limitations and respiratory problems [22-24]. Although the mechanisms are not fully known, it was recognized the positive effects of exercise on mood through physiological and biochemical mechanisms, including endorphins, mitochondria and neurotransmitters $[25,26]$.

A multi-center study conducted in Europe evaluated the practice of self-reported PA in hours per week in $\mathrm{CF}$ subjects. The PA was directly related to the social functioning domain in the HRQoL questionnaire, and in the female gender there were inferior results regarding the practice of self-reported PA, muscle strength and functional limitation in the HRQoL questionnaire [24]. Selvadurai et al. evaluated the PA in 148 children with CF through daily reports. They found a correlation 
between the levels of PA with quality of life and gender, adolescent girls were less active and had a greater decline in lung function [27].

The SK score remains a useful tool for monitoring the severity of cystic fibrosis, adequately reflecting functional impairment obtained by six minute walk test and changes in the chest X-ray [28]. The SK score also may have an inverse correlation with treatment adherence in adults, that is, more severe patients end up improving self-treatment [29]. However, in our data, we obtained a better clinical score in the most active patients.

In addition, a greater number of hospitalizations and days hospitalized in the last year were found in the group practicing $\mathrm{PA} \leq 2$ times/week. It is important to note that in this study, individuals with CF had preserved pulmonary function, with no differences between groups regarding the data on spirometry and bacteriology. These data reinforce the results that individuals with better frequency in PA are less hospitalized. Pérez et. al. concluded that physical fitness in children is associated with a lower risk of hospitalization [30]. Vandekerckhove et al. [5] correlated last year hospitalization of children with CF with physical health, school functioning and total HRQoL score. Hospitalization rates in this population reflect pulmonary exacerbations, morbidity, mortality and are associated with worse disease management $[31,32]$.

Limitations of the study include cross-sectional design and use of self-report questionnaire as a measure of PA. Cross-sectional evaluation precludes inferences over time. Self-report is a subjective data, in which the patient may overestimate the reports of PA practice data. The lack of evaluation with accurate measurements of PA makes it impossible to directly measure the time and intensity of PA performed. However, the use of questionnaires may be a good option when other more precise measurements are not possible. There is no standardized and validated instrument for selfreported PA evaluation in children and adolescents with CF. Although some questionnaires were tested, none were universally accepted[33]. Having a specific tool to assess self-reported PA in this population would facilitate the multiprofessional team in the outpatient follow-up of the PA practices of CF subjects.

In conclusion, the evaluation of self-reported frequency of PA in pediatric and adolescent subjects attending to an outpatient CF clinic in Southern Brazil demonstrated that most subjects did not reach the WHO recommendations for the practice of PA. However, individuals who regularly practice PA (at least 3 times a week) have better HRQoL, clinical score and fewer hospitalizations. The efforts made by the multidisciplinary team to guide and encourage regular PA practice must be emphasized.

\section{Acknowledgements}

We would like to thank the entire HCPA CF team and the collaborators who made the present study possible. The financing source was obtained through the Fundo de Incentivo à Pesquisa (FIPE) of Hospital de Clínicas de Porto Alegre.

\section{References}

1. ElbornJS.Cysticfibrosis. Lancet.2016;388(10059):2519-31.

2. Kieninger E, Yammine S, Korten I, Anagnostopoulou P, Singer F, Frey U, et al. Elevated lung clearance index in infants with cystic fibrosis shortly after birth. Eur Respir J. 2017;50(5):1700580.

3. Ramsey K, Ratjen F, Latzin P. Elucidating progression of early cystic fibrosis lung disease. Eur Respir J. 2017;50:1701916.

4. Almajed A, Lands LC. The evolution of exercise capacity and its limiting factors in Cystic Fibrosis. Paediatr Respir Rev. 2012;13(4):195-9.

5. Vandekerckhove K, Keyzer M, Cornette J, Coomans I, Pyl F, De Baets F, et al. Exercise performance and quality of life in children with cystic fibrosis and mildly impaired lung function: relation with antibiotic treatments and hospitalization. Eur J Pediatr. 2017;176(12):1689-96.

6. Radtke T, Sj N, Hebestreit H, Kriemler S. Physical exercise training for cystic fibrosis (Review). Cochrane Database Syst Rev. 2017;11(11):CD002768.

7. Cox NS, Alison JA, Holland AE. Interventions for promoting physical activity in people with cystic fibrosis. Cochrane Database Syst Rev. 2013;(12):CD009448.

8. Prince SA, Adamo KB, Hamel ME, Hardt J, Gorber SC, Tremblay M. A comparison of direct versus selfreport measures for assessing physical activity in adults: A systematic review. Int J Behav Nutr Phys Act. 2008;5(56)1-24. 
9. Collaco JM, Blackman SM, Raraigh KS, Morrow CB, Cutting GR, Paranjape SM. Self-reported exercise and longitudinal outcomes in cystic fibrosis: A retrospective cohort study. BMC Pulm Med. 2014;14(1):1-8.

10. Quittner AL, Buu A, Messer MA, Modi AC, Watrous M. Development and Validation of the Cystic Fibrosis Questionnaire in the United States. Chest. 2005;128(4):2347-54.

11. Rosenstein BJ. What is a cystic fibrosis diagnosis? Vol.19, Clinics in Chest Medicine. 1998;19(3):423-41.

12. World Health Organization. Global recommendations on physical activity for health. Geneva: World Health Organization; 2010.

13. Athanazio RA, Silva Filho LVRF, Vergara AA, Ribeiro AF, Riedi CA, Procianoy EFA, et al. Brazilian guidelines for the diagnosis and treatment of cystic fibrosis. J Bras Pneumol. 2017;43(3):219-45.

14. Ainsworth BE, Haskell WL, Herrmann SD, Meckes N, Bassett DR, Tudor-Locke C, et al. 2011 compendium of physical activities: A second update of codes and MET values. Med Sci Sports Exerc. 2011;43(8):1575-81.

15. Quittner AL, Sweeny S, Watrous M, Munzenberger P, Bearss K, Gibson Nitza A, et al. Translation and linguistic validation of a disease-specific quality of life measure for cystic fibrosis. J Pediatr Psychol. 2000;25(6):403-14.

16. Rozov T, Cunha MT, Nascimento O, Quittner AL, Jardim JR. Validação lingüística dos questionários de qualidade de vida em fibrose cística. J Pediatr (Rio J). 2006;82(2):151-6.

17. Shwachman H, Kulczycki LL. Long-term study of one hundred five patients with cystic fibrosis: studies made over a five- to fourteen-year period. AMA J Dis Child. 1958;96(1):6-15.

18. Pereira CA. Espirometria. J Bras Pneumol. 2002;28(3):S1-82.

19. Polgar G, Weng TR. The functional development of the respiratory system. From the period of gestation to adulthood. Am Rev Respir Dis. 1979;120(3):625-95.

20. Knudson RJ, Slatin RC, Lebowitz MD, Burrows B. The maximal expiratory flow volume curve. Normal standards, variability, and effects of age. Am Rev Respir Dis. 1976;113(5):587-600.
21. Hulzebos EH, Dadema T, Takken T. Measurement of physical activity in patients with cystic fibrosis: A systematic review. Expert Rev Respir Med. 2013;7(6):647-53.

22. Ruf KC, Fehn S, Bachmann M, Moeller A, Roth K, Kriemler $S$, et al. Validation of activity questionnaires in patients with cystic fibrosis by accelerometry and cycle ergometry. BMC Med Res Methodol. 2012;12:(43)1-9.

23. Bize R, Johnson JA, Plotnikoff RC. Physical activity level and health-related quality of life in the general adult population: a systematic review. Prev Med. 2007;45(6):401-15.

24. Urquhart D, Sell Z, Dhouieb E, Bell G, Oliver S, Black R, et al. Effects of a supervised, outpatient exercise and physiotherapy programme in children with cystic fibrosis. Pediatr Pulmonol. 2012;47(12):1235-41.

25. Hebestreit H, Schmid K, Kieser S, Junge S, Ballmann M, Roth K, et al. Quality of life is associated with physical activity and fitness in cystic fibrosis. BMC Pulm Med. 2014;14(26):1-9.

26. Lubans D, Richards J, Hillman C, Faulkner G, Beauchamp $M$, Nilsson $M$, et al. Physical activity for cognitive and mental health in youth: A systematic review of mechanisms. Pediatrics. 2016;138(3):e20161642.

27. Mikkelsen K, Stojanovska L, Polenakovic M, Bosevski M, Apostolopoulos V. Exercise and mental health. Maturitas. 2017;106:48-56.

28. Selvadurai HC, Blimkie CJ, Cooper PJ, Mellis CM, Van Asperen PP. Gender differences in habitual activity in children with cystic fibrosis. Arch Dis Child. 2004;89:928-33.

29. Stollar F, Adde FV, Cunha MT, Leone C, Rodrigues JC. Shwachman-Kulczycki score still useful to monitor cystic fibrosis severity. Clinics (Sao Paulo). 2011;66(6):979-83.

30. Dalcin PDTR, Rampon G, Pasin LR, Ramon GM, Abrahão CLDO, Oliveira VZ. Adesão ao tratamento em pacientes com fibrose cística. J Bras Pneumol. 2007;33(6):663-70.

31. Pérez M, Groeneveld IF, Santana-Sosa E, Fiuza-Luces C, Gonzalez-Saiz L, Villa-Asensi JR, et al. Aerobic fitness is associated with lower risk of hospitalization in children with cystic fibrosis. Pediatr Pulmonol. 2014;49(7):641-9. 
32. Feiten TS, Flores JS, Farias BL, Rovedder PME, Camargo EG, Dalcin PTR, et al. Respiratory therapy : a problem among children and adolescents with cystic fibrosis. J Bras Pneumol. 2016;42(1):29-34.

33. Cogen JD, Oron AP, Gibson RL, Hoffman LR, Kronman MP, Ong T, et al. Characterization of inpatient cystic fibrosis pulmonary exacerbations. Pediatrics. 2017;139(2): e20162642.
34. Wells GD, Wilkes DL, Schneiderman-Walker J, Elmi M, Tullis E, Lands LC, et al. Reliability and validity of the habitual activity estimation scale (HAES) in patients with cystic fibrosis. Pediatr Pulmonol. 2008;43(4):345-53.

Received: 04/13/2020

Recebido: 13/04/2020

Approved: 07/23/2020

Aprovado: 23/07/2020 